\title{
Appraisal of Hybrid Foundations on Loose Granular Soil of Western Saudi Arabia
}

\author{
Qazi Umar Farooq ${ }^{*}$, Ahmed B. Shaath \\ Department of Civil Engineering, Islamic University of Madinah, Saudi Arabia \\ Received 11 April 2020; received in revised form 28 June 2020; accepted 10 July 2020 \\ DOI: https://doi.org/10.46604/peti.2020.5515
}

\begin{abstract}
Western Saudi Arabia is the most important geographic location for the Islamic world. Millions of pilgrims annually visit the region. To accommodate this huge number of pilgrims, various tall buildings are constructed, yet there is a need for many more. The demolition of old buildings is also in progress. The soil supporting of the foundations mostly comprises sand with varying relative density. Most of the buildings are supported by conventional foundations, which require deep excavation for low relative densities. The combinations of pile and raft or hybrid foundations have been effectively used in tall buildings around the globe. In this research, COMSOL Multiphysics FEM analysis has been adopted to investigate the performance of a hybrid foundations with different pile combinations supported on loose granular soil. The results reflect the effective utilization of the hybrid foundation on loose sand. The arrangement of piles in the foundation system can affect the economy and safety of the structure.
\end{abstract}

Keywords: loose sand, hybrid foundation, pile arrangement, foundation settlement

\section{Introduction}

The western geographic region of the Kingdom of Saudi Arabia is an extremely vital geopolitical zone. It not only contains the two holiest cities of Islam but also has an important port city Jeddah. The kingdom's 2030 vision for the development of the tourism sector will likely boost the inflow of the tourists and the pilgrims [1]. The government is also planning to build a mega tourist destination named NEOM which is full-fledged smart city with various tourist attractions [2]. Hence, there is a huge potential for infrastructure expansion in the region.

The region is surrounded by various mountain ranges. The structure supporting soil mainly comprises sand with varying degrees of relative density [3]. Foundation settlement in loose sand is a universal phenomenon [4]. During the service life of a structure, foundations supported on sands, which have lower relative density may experience large settlements due to their low shear strength and high compressibility [5]. Under inadequate geotechnical conditions, conventional isolated footings or even raft may not perform very well. The shallow foundations supported by weak soil may cause undesirable distress in the building structure. The circumstances can become worse if there is a seismic activity [6].

The classical pile foundation system has been effectively used for vital projects under unfavorable soil conditions; however, it has several disadvantages as well. There are numerous issues that can arise during the foundation construction [7]. Possible problems are categorized as follows: pile formation problems, concrete failing, reinforcement installation issues,

* Corresponding author. E-mail address: qaziumar@gmail.com

Tel.: +966-54-8453411; Fax: +966-14-845-6139 
working load failing, and Foundation failure due to the settlement [8]. Deep foundations often intercept groundwater tables and require expensive dewatering. The deep foundations are subjected to high lateral loading and perform poorly if liquefaction occurs followed by the seismic activity [9-10].

The foundation performance of the raft can be enhanced by adding the piles. The ideal bearing capacity and controlled settlement circumstances can be achieved by properly designing the pile placement [11]. The Pile-raft foundation system had been economically and effectively used in various parts of the world [12-13]. A parametric study conducted by using 'Plaxis' reveals that the disconnected piled raft (DPR) foundation is more efficient for soft soils. The system performed better for heavy structures [14].

The piled raft foundation problem can be solved effectively through a combination of structural responses and geotechnical characteristics without a complex model of the soil and foundation. Applying the pile 'load-cut off' procedure within piles capacity, the piles are dominant in terms of the piled raft behavior. In case the load is beyond the piles-capacity, the raft behavior is dominant [15]. Various studies have shown that the addition of limited piles in length and number may serve a purpose. An experimental study conducted to analyze the behavior of pile-raft system showed that the small number of piles within the group had a low contribution to the overall load carrying capacity. The failure load for a piled raft is greater than standing pile group containing the same number of piles. This difference was increased by increasing the number of piles [16]. Whilst most of the above-referred studies focus on the design procedures and performance of pile raft system on varying soil types, the evaluation of the pile placement and quantity under the raft, for particular geotechnical conditions has not been well understood. Most of the experimental and numerical models have considered symmetric distribution of piles under the raft, which can be an economical and over-engineering option.

In this research, the single term "Hybrid Foundation" is coined to designate the pile-raft, discontinued pile-raft, and other similar combined foundation systems. This paper discusses the philosophy of piles using the arrangement for the hybrid foundations under varying loading conditions. The research specifically targets the loose granular soils of western Saudi Arabia. However, results can be utilized for the design of Hybrid foundations on other similar geotechnical conditions.

\section{Soil Properties}

The study mainly focuses on the loose sand conditions of western Saudi Arabia. The soil samples were collected from the western city, Al Madinah. The samples were collected from an open pit at 1-m depth from the ground surface. The index properties of the soil were determined in laboratory. As per the unified soil classification system (USCS), the soil is classified as "Poorly Graded Sand" with symbol 'SP' [17]. It is non-plastic in nature (Liquid Limit = 0, Plastic Limit = 0, Plasticity Index $=0$ ). The sand is located at 7.5 YR 5/4 (Brown) on the Munsell soil color chart [18]. The grain size distribution curve of the considered soil is shown in Fig. 1 . The uniformity coefficient $(\mathrm{Cu})$ of the sand was $=3.64$.

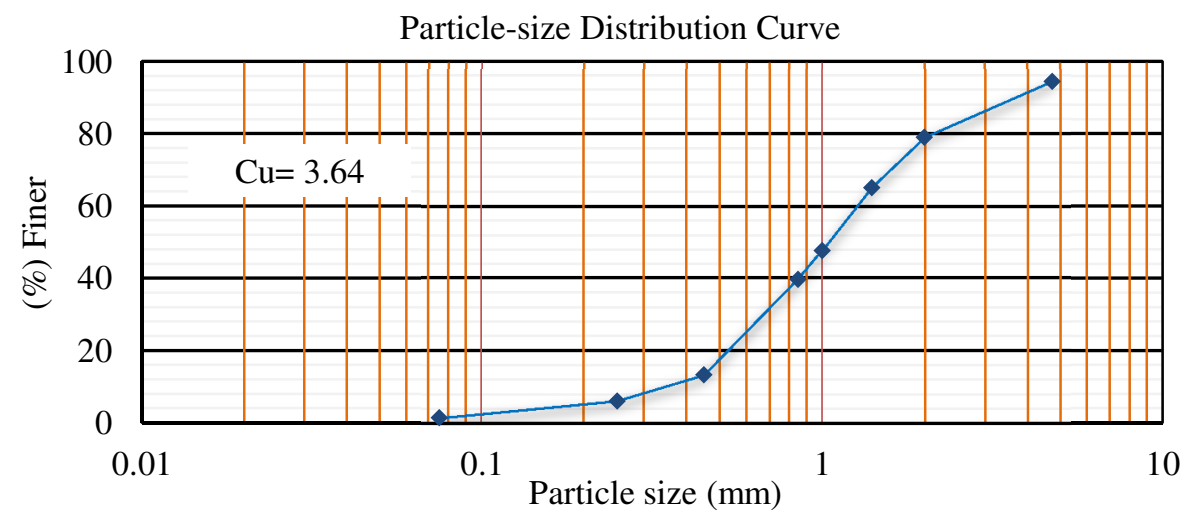

Fig. 1 Particle-size distribution curve of al Madinah sand 
The maximum and minimum void ratios $\left(\mathrm{e}_{\max }\right.$ and $\mathrm{e}_{\min }$ ) of the sand were also determined in the laboratory and summed up in Table 1. In order to represent the loose sand conditions, a low relative density value of Dr. $=30 \%$ has been selected in the study. The fundamental soil parameters required for the numerical study were then determine by using standard empirical correlations [19]. The soil parameters used in this study are shown in Table 2.

Table 1 Minimum and maximum void ratio

\begin{tabular}{|c|c|c|}
\hline Limit & Unit weight $\gamma\left(\mathrm{kN} / \mathrm{m}^{3}\right)$ & Void ratio e (\%) \\
\hline Maximum & 15.99 & $54.60 \%$ \\
\hline Minimum & 13.79 & $79.27 \%$ \\
\hline
\end{tabular}

Table 2 Soil Parameters for numerical modelling

\begin{tabular}{|c|c|c|c|c|c|}
\hline $\begin{array}{c}\text { Relative } \\
\text { Density } \mathrm{D}_{\mathrm{r}}(\%)\end{array}$ & $\begin{array}{c}\text { Void ratio } \\
\mathrm{e}(\%)\end{array}$ & $\begin{array}{c}\text { Angle of Internal } \\
\text { Friction } \varnothing(\mathrm{rad})\end{array}$ & $\begin{array}{c}\text { Angle of } \\
\text { Friction } \delta(\mathrm{rad})\end{array}$ & $\begin{array}{c}\text { Unit weight } \\
\gamma\left(\mathrm{kN} / \mathrm{m}^{3}\right)\end{array}$ & $\begin{array}{c}\text { The angle of } \\
\text { dilation } \psi(\mathrm{rad})\end{array}$ \\
\hline 30 & 71.87 & 0.531 & 0.398 & 14.32 & 0.007 \\
\hline
\end{tabular}

\section{Methodology}

The strategic objective of this research is to evaluate the performance of the hybrid foundation under varying loading conditions, with different pile placement (pile layout). The pile placement is varied in terms of the number and location. The FEM base numerical analysis has been adopted in this research. The numerical modeling has been done by using the solid mechanic's module of COMSOL Multiphysics software [20]. It was possible with the help of software to model the pile and soil together.

Three (03) cases of hybrid foundations were considered in this study. Each case differs in terms of the pile layout. The 20-m by 20-m layout was considered in the model. The soil depth of $15-\mathrm{m}$ was adopted. The hybrid foundations consisted of 1-m thick raft, along with 12-m long piles. The Pile diameter was 0.5-m in all cases. There were six (06) piles used in Case 1, the pile layout was straight. Only three (03) piles were used in the staggered layout presented in Case 2. However, Case 3 had nine (09) piles placed in three (03) groups each comprises three piles. The pile positioning and geometry of the hybrid foundation models for Cases 1, 2, and 3 are shown respectively in Figs. 2(a)-2(c).

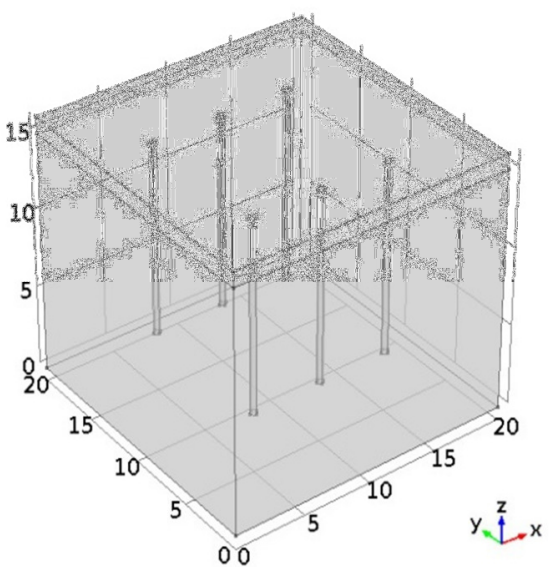

(a) straight layout (Case 1)

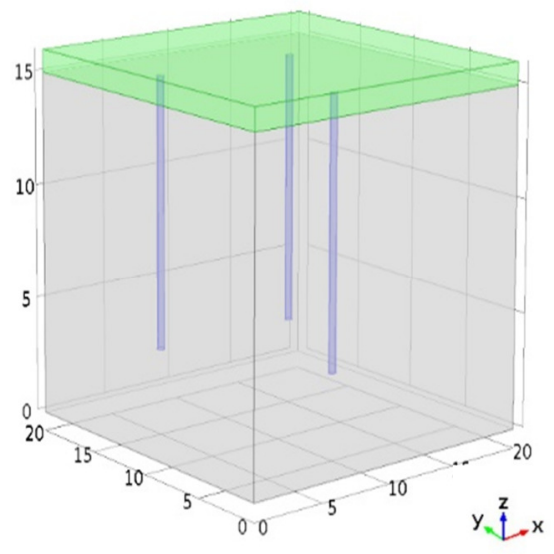

(b) staggered layout (Case 2)

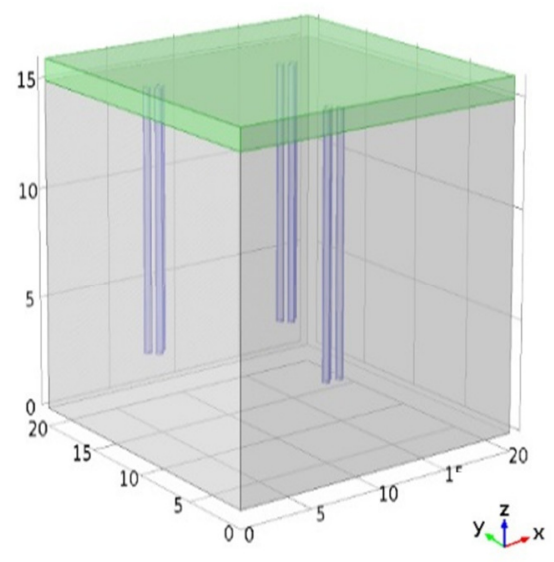

(c) grouped pile layout (Case 3)

Fig. 2 Hybrid foundation cases

The soil properties defined in section 2 were incorporated into the model as the loose granular material. The soil is modelled as Mohr-Coulomb's material [21], with the following governing equations:

The function of normal and shear stress:

$$
\tau_{\mathrm{f}}=\mathrm{f}(\sigma)
$$


The linear function:

$$
\tau_{\mathrm{f}}=\mathrm{c}+\sigma \tan \Phi
$$

The linear function in terms of effective stress:

$$
\tau_{\mathrm{f}}=\mathrm{c}^{\prime}+\sigma^{\prime} \tan \Phi^{\prime}
$$

Where $\tau_{\mathrm{f}}$ is the shear stress, $\sigma$ is the normal stress, $\mathrm{c}$ is defined as material cohesion, $\Phi$ is the frictional angle of the soil. c' and $\sigma^{\prime}$ are respective values in terms of effective stresses. The hybrid foundation material is assumed to be reinforced concrete. The concrete is considered as linear elastic material with typical values of density Poisson's ratio and elasticity modulus.

\subsection{Loadings}

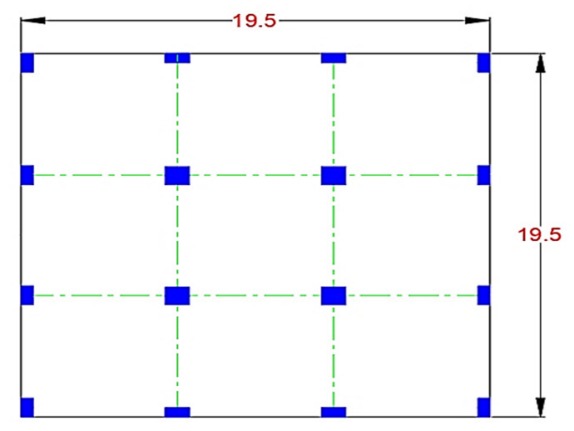

Fig. 3 Typical floor plan of the building

The typical floor plan of the building is indicated in Fig. 3. The floor area of 19.5-m x 19.5-m is adopted to overlay the 20-m x 20-m raft of hybrid foundation. Building design loads are taken as per Building Code Requirements for Structural Concrete (ACI 318M-11) [22]. Live load (LL)=10kN/m² was applied to all floors. The Self-weight of the structure has been considered in the analysis by using COSOL Multiphysics 'body load' built-in module. It can accurately apply the self-weight of the object, by using its geometry, material density, and gravity. Table 3 shows the number of stories and the estimated design load:

Table 3 Estimate design load/stress

\begin{tabular}{|c|c|}
\hline Number of stories & Estimate design load (kPa) \\
\hline 1 & 54.4 \\
\hline 2 & 108.8 \\
\hline 3 & 163.2 \\
\hline 4 & 217.6 \\
\hline 5 & 272 \\
\hline
\end{tabular}

\subsection{Numerical modeling}

The surface load is applied on top of the raft as per Table 3. Each case has been tested with the above five loading conditions. The sides of the raft were kept free. Two built-in material models have been utilized in the FEM analysis. The first material model is the concrete, which has been adopted for hybrid foundation material and uses linear elastic equations. The second material model is the Elastoplastic Mohr-Coulomb's model used for the 15-m thick layer of loose granular soil, supporting the hybrid foundation and its influence zone. Whereas, the natural ground strata, supporting the overall system (Hybrid foundation and surrounding soil) is considered as a spring foundation. The spring constant of the soil was taken as $100 \mathrm{MN} / \mathrm{m} \cdot \mathrm{m}^{2}$. The analysis was done considering the stationary condition. The system has been analyzed by using a flexible generalized minimum residual (FGMERS) iterative solver. The convergence plot for the solution of Case 2 with $272 \mathrm{kPa}$ load is presented in Fig. 4. 


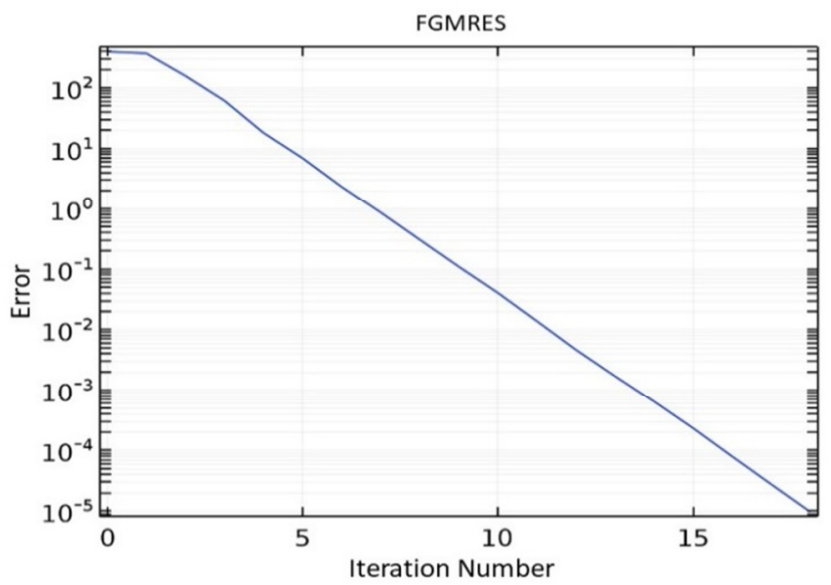

Fig. 4 Convergence Plot for Case 2

\section{Analysis Results}

The results obtained from the FEM based stress-strain study are presented in this section. Each case has been tested for all the five designed loads. The results are plotted for total displacement counter, stress or pressure distribution, and total displacement at critical sections. The plots for each case against the above mention parameters are represented separately in the following subsections:

\subsection{Straight pile layout}

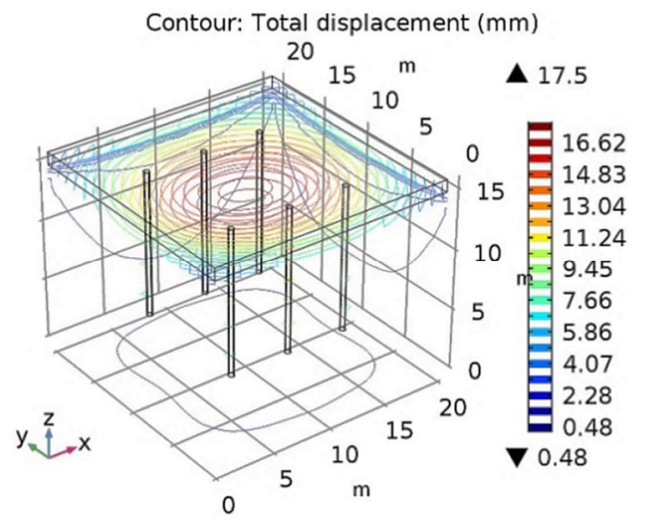

(a) displacement contour

Slice: Total displacement $(\mathrm{mm})$

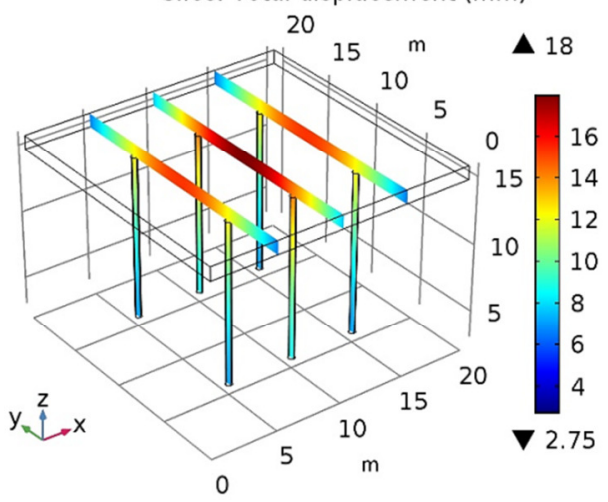

(c) displacement at critical sections (Y-Z plane)

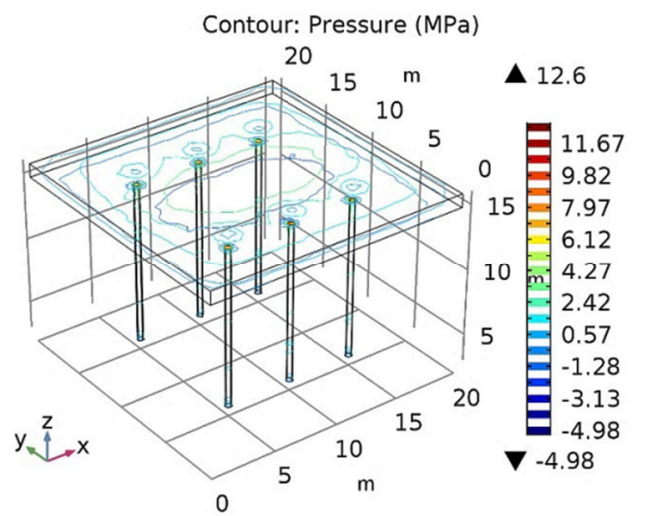

(b) stress distribution

Slice: Total displacement $(\mathrm{mm})$

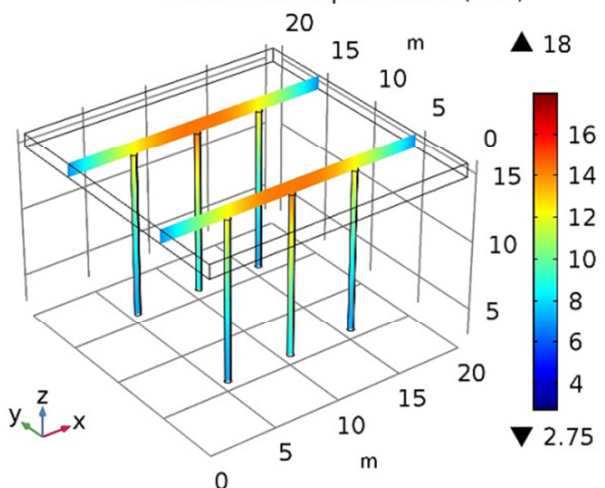

(d) displacement at critical sections (X-Z plane)

Fig. 5 Displacement and Pressure distribution for Straight Pile layout (Case 1)

The FEM analysis results for straight Pile layout (Case 1) are presented in Fig. 5. The results are plotted for the maximum applied load of $272 \mathrm{kPa}$. The top left diagram shows the total displacement contour, it can be seen that the maximum displacement occurs at the center of the raft. The maximum stress developed at the intersection of pile and raft (top right 
diagram). The diagrams at the bottom of the figure display the displacement at sections located at the center line of piles in $\mathrm{z}-\mathrm{X}$ and z-y planes. In this case, the maximum foundation displacement is $18.0 \mathrm{~mm}$ and the maximum pressure is $16.32 \mathrm{MPa}$. The pressure plot represents the mean stress value at any given location. Mathematically, it is 1/3 of the first invariant of the Cauchy or true stress tensor. It can be obtained by:

$$
\pi=\left(\sigma_{11}+\sigma_{22}+\sigma_{33}\right) / 3
$$

Where $\pi$ is the pressure (mean stress) in $\mathrm{MPa}, \sigma_{11}, \sigma_{22}$, and $\sigma_{33}$, are principal stresses.

\subsection{Staggered piles}

The Case 2 presents the staggered pile layout only three piles were used. The results of the numerical analysis at $272 \mathrm{kPa}$ load are shown in Fig. 6. Similar to Case 1, the displacement and pressure counters are presented in the top two diagrams. The bottom diagrams show displacement at sections, located on the centerline of the piles. The maximum displacement, in Case 2 , was 19.5-mm positioned at the center of the raft. The maximum stress was 14.35-Mpa located at the pile-raft joint. Like Case 1 noticeable stresses were observed throughout the pile length.

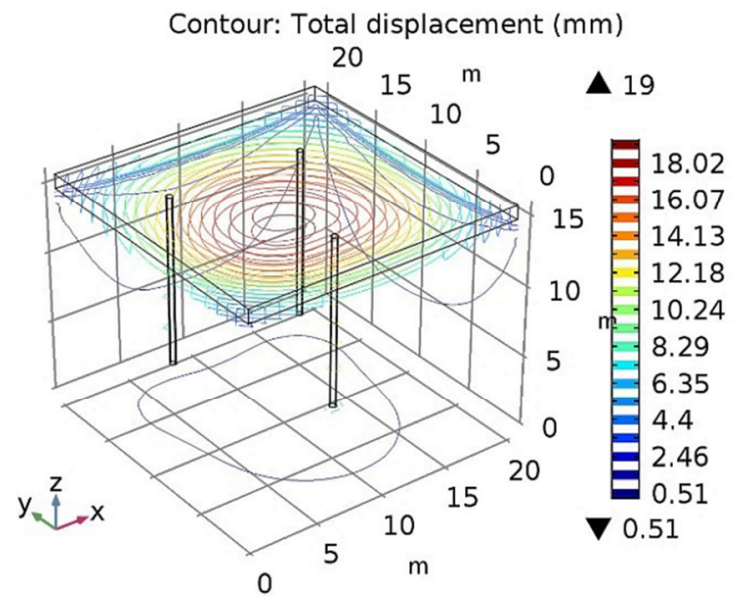

(a) displacement contour

Slice: Total displacement $(\mathrm{mm})$

20

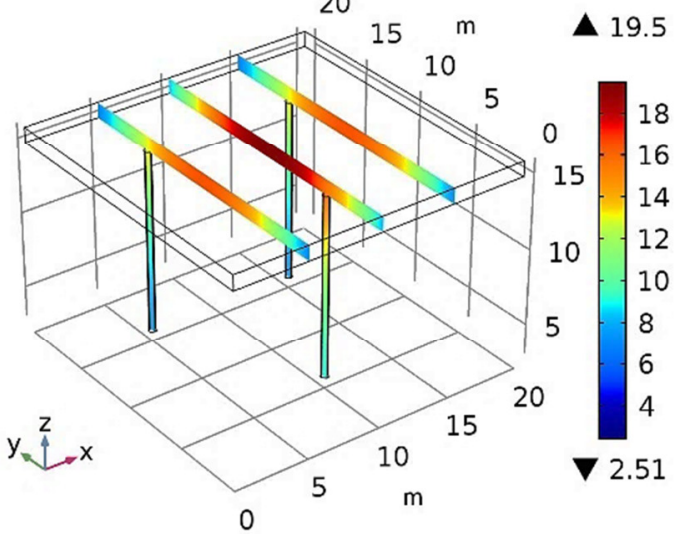

(b) displacement at critical sections (Y-Z Plane)

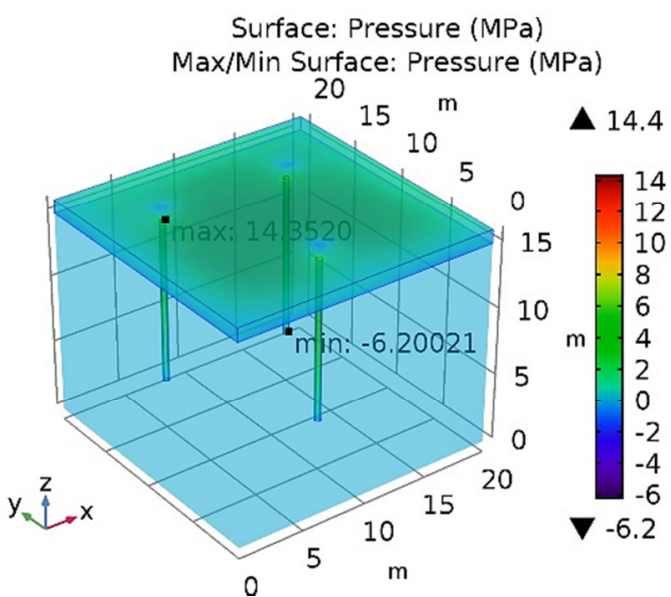

(c) stress distribution

Fig. 6 Displacement and pressure distribution for staggered pile layout (Case 2)

\subsection{Group piles}

The last case presents the group piles. In this case, nine (09) piles were used in the three groups at a staggered position. The displacement and stress contours generated from FEM results are shown in Fig. 7. The maximum displacement was 29.36 $\mathrm{mm}$, while the maximum pressure was just $0.24 \mathrm{Mpa}$. 


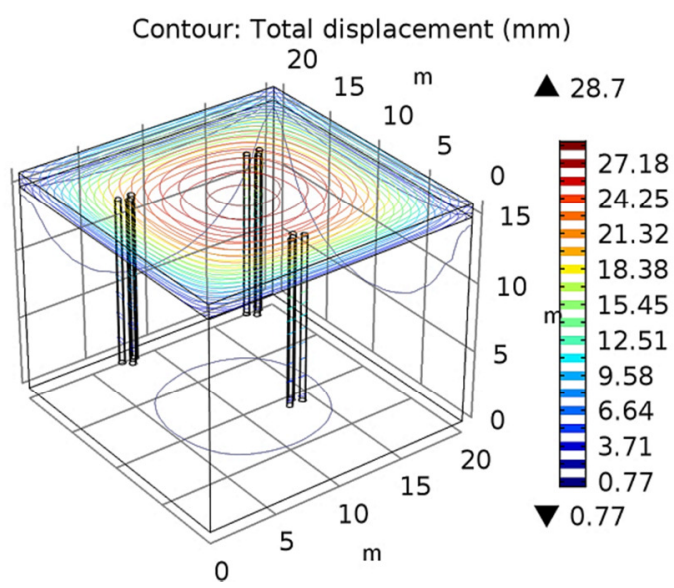

(a) displacement contour

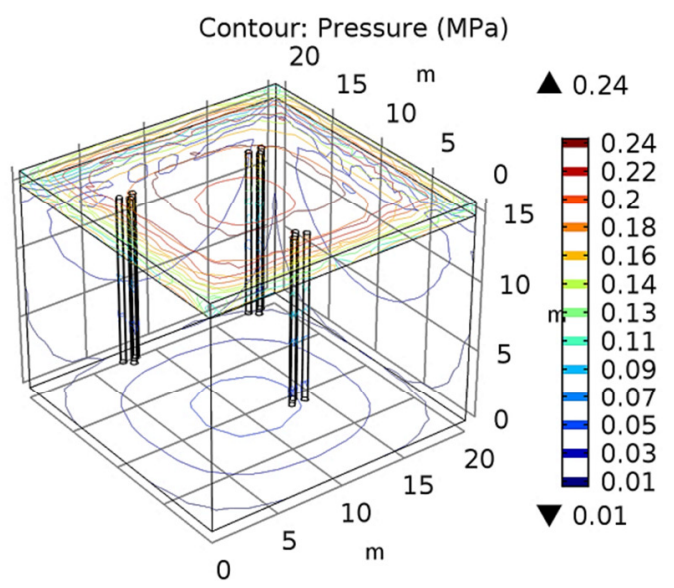

(b) stress distribution

Fig. 7 Displacement and pressure distribution for group pile layout (Case 3)

\section{Discussions}

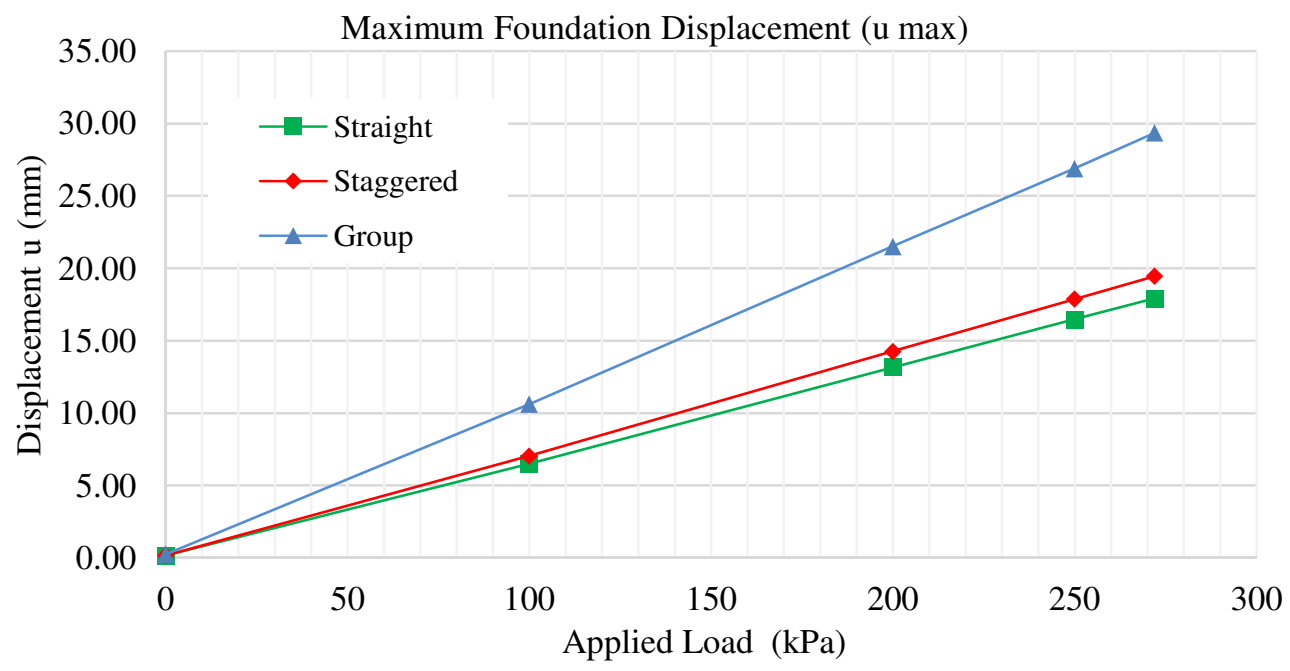

Fig. 8 Summary of FEM results (displacement)

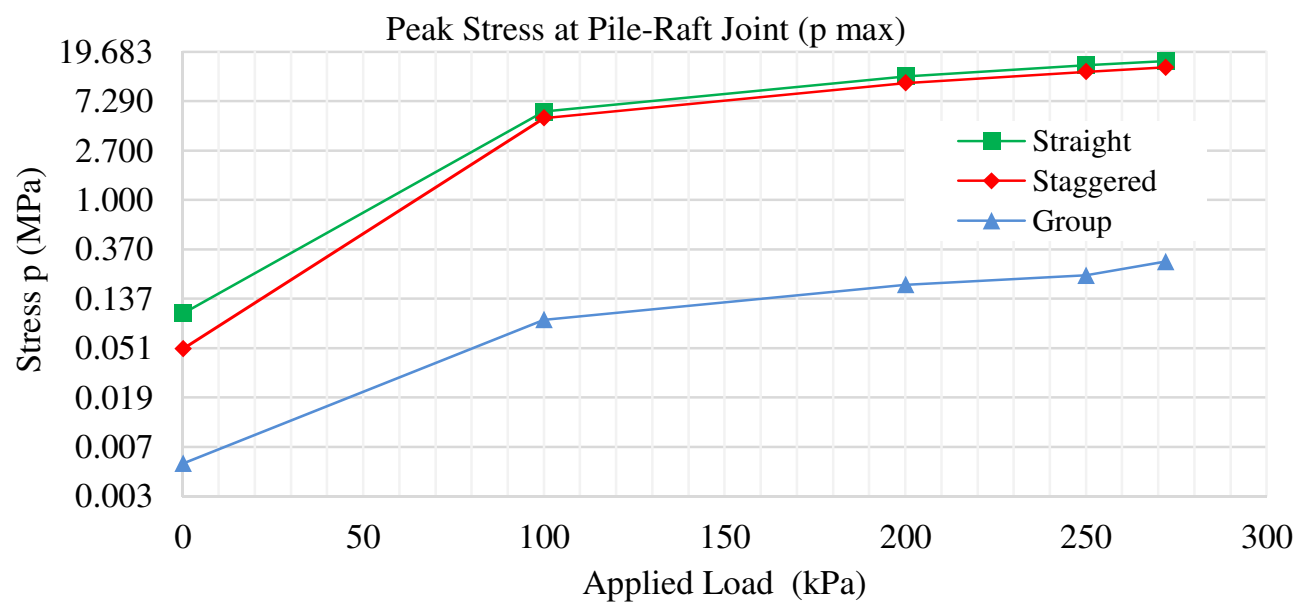

Fig. 9 Summary of FEM results (stresses)

In all of the three cases, the soil stresses are very low, i.e., they are well above the bearing capacity of the soil. The maximum displacement data obtained from all the foundation cases under five different loading conditions is plotted in Fig. 8. The foundation system with the straight layout and six piles has revealed the best resistance against the overall settlement of the foundation system. The hybrid foundation with three staggered piles has a consistent settlement with slightly higher values 
than that of straight pile layout. The group pile system has shown the maximum settlement. The load settlement curve has the same pattern for all three cases. The primary reason for a higher settlement in the group pile system is the self-weight of the system.

In the hybrid foundation system, the pile raft joint plays a very significant role, stresses at this location are very critical and governs the overall safety of the building. The maximum stress developed at the pile-raft joint in the foundation system is selected for each case. These stresses are then plotted for all three cases against five loadings in Fig. 9. The stresses in the group pile system were very low as compared to the staggered and straight foundation systems. Therefore, stresses (dependent variable) in Fig. 9 were plotted on a natural logarithmic scale. If staggered and straight systems compared to the joint stresses in later are slightly higher, the low stresses in the group pile system are due larger supporting cross-sectional areas.

The hybrid foundation system with group piles (Case-3) has displayed the maximum settlement. The deformed shape of the foundation system is presented in Fig. 10. The distortion (sagging) of the raft and pile bending can be clearly seen in the Fig. 10

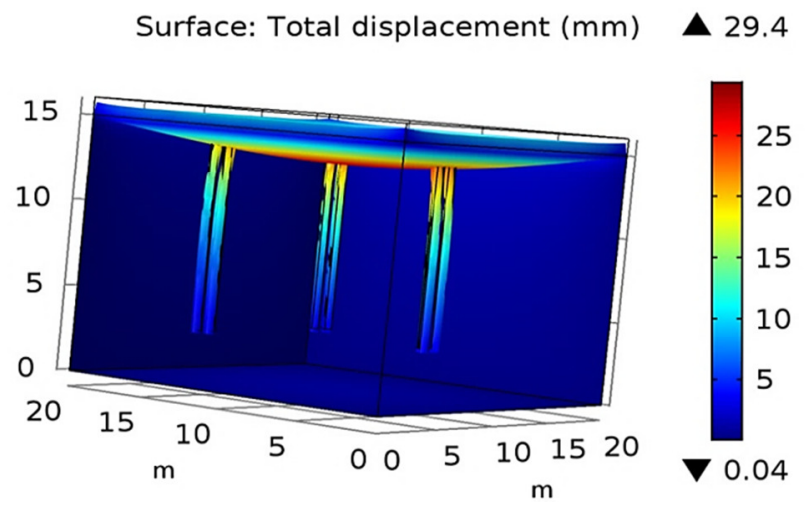

Fig. 10 Deformed shape for Case 3

The volume of reinforced concrete used in the foundation system plays a very important part in the overall project economy. The volume of concrete required for straight, staggered, and group foundation system was respectively 456.55, 428.27 and $484.82 \mathrm{~m}^{3}$ in Fig. 11. Since the pile diameter and length is the same in all cases, the volume difference is the numerical reflection of the pile number. The hybrid foundation system with staggered piles is the most economical one, whereas the foundation system having group piles is relatively extravagant.

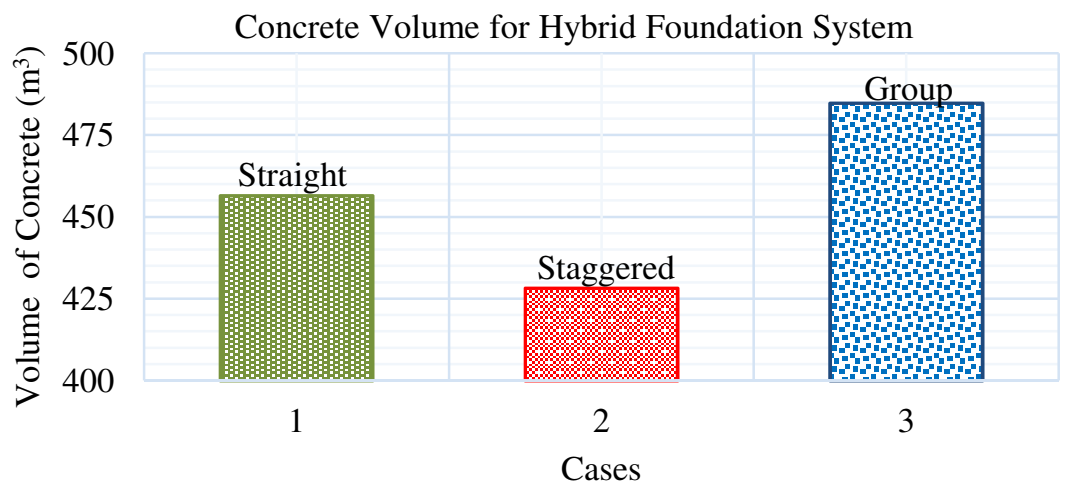

Fig. 11 Concrete volume use in different foundation systems

\section{Conclusions}

The hybrid foundation system can be effectively applied to the buildings resting on loose granular soil. The system distributes the load over the larger surface area of the soil and utilizes friction, bearing capacity, and tip resistance. The system requires fewer piles, as compared to the conventional pile foundation system. Various pile layouts can be adopted in the hybrid 
foundation system; however, the staggered pile layout is most effective and economic. Pile foundations placed in subgroups can be applied to reduce the stresses in the pile raft joint. Nevertheless, this type of combination is not only uneconomical but is relatively risky. The combination can be used for heavily loaded structures, where stresses at the pile raft joint are critical. The excessive settlements can be controlled either by soil improvement or foundation design modifications. This research was carried out on loose granular soil of Madinah Saudi Arabia. On the other hand, results can be applied to other comparable geographic regions.

The performance of Hybrid foundation, under fluctuating groundwater conditions, will be investigated as a part of future research plan, precise modeling of partly saturated conditions will be a potential research challenge and laboratory investigations will be planned to reinforce the numerical study. The effect of pile material, cross-sectional and longitudinal geometry on pile quantity of a hybrid foundation system is suggested as a prospective research topic.

\section{Conflicts of Interest}

The authors declare no conflict of interest.

\section{References}

[1] M. Abuhjeeleh, "Rethinking tourism in Saudi Arabia: royal vision 2030 perspective," African Journal of Hospitality, Tourism, and Leisure, vol. 8, no. 5, pp. 1-16, 2019.

[2] A. A. Farag, "The story of NEOM City: opportunities and challenges," New Cities and Community Extensions in Egypt and the Middle East, Springer Press, June 2018, pp. 35-49.

[3] G. F. Brown, D. L. Schmidt, and A. C. Huffman Jr., "Geology of the arabian peninsula: shield area of western saudi arabia," US Geological Survey, 1989.

[4] J. B. BURLAND, M. C. Burbidge, E. J. Wilson, P. R. Vaughan, C. R. I. Clayton, P. R. Filho, et al., "Discussion. settlement of foundations on sand and gravel.," Proc. of the Institution of Civil Engineers, December 1986, pp. 1625-1648.

[5] J. He, J. Chu, and H. Liu, "Undrained shear strength of desaturated loose sand under monotonic shearing," Soils and Foundations, vol. 54, no. 4, pp. 910-916, July 2014.

[6] M. T. Naqash, Q. U. Farooq, and O. Harireche, "Seismic evaluation of steel moment resisting frames (MRFs)—supported by loose granular soil,” Open Journal of Earthquake Research, vol. 8, no. 2, pp. 37-51, May 2019.

[7] J. Berrill and S. Yasuda, "Liquefaction and piled foundations: some issues," Journal of Earthquake Engineering, vol. 6, pp. $1-41,2002$.

[8] G. Madabhushi, J. Knappett, and S. Haigh, Design of pile foundations in liquefiable soils, World Scientific, 2009.

[9] T. Thavaraj, W. L. Finn, and G. Wu, "Seismic response analysis of pile foundations," Geotechnical and Geological Engineering, vol. 28, no. 3, pp. 275-286, March 2010.

[10] W. L. Finn, “A study of piles during earthquakes: Issues of design and analysis," Bulletin of Earthquake Engineering, vol. 3, no. 2, pp. 141, January 2005.

[11] H. G. Poulos, "Piled raft foundations: design and applications," Geotechnique, vol. 51, no. 2, pp. 95-113, March 2001.

[12] H. G. Poulos, J. C. Small, and H. Chow, "Piled raft foundations for tall buildings," Geotechnical Engineering Journal of the SEAGS \& AGSSEA, vol. 42, no. 2, pp. 78-84, June 2011.

[13] M. Majima and T. Nagao, 14. Behaviour of piled raft foundation for tall building in Japan, Thomas Telford, 2000.

[14] B. Hor, M. J. Song, M. H. Jung, Y. H. Song, and Y. H. Park, “A 3D FEM analysis on the performance of disconnected piled raft foundation,” Japanese Geotechnical Society Special Publication, vol. 2, no. 34, pp. 1238-1243, 2016.

[15] D. D. C. Nguyen, S. B. Jo, and D. S. Kim, "Design method of piled-raft foundations under vertical load considering interaction effects," Computers and Geotechnics, vol. 47, pp. 16-27, August 2012.

[16] M. Y. Fattah, M. A. Yousif, and S. M. Al-Tameemi, "Effect of pile group geometry on bearing capacity of piled raft foundations," Structural Engineering and Mechanics, vol. 54, no. 5, pp. 829-853, 2015.

[17] ASTM Committee D-18 on Soil and Rock, Standard practice for classification of soils for engineering purposes (unified soil classification system), ASTM International, 2006.

[18] M. Color, Munsell soil color charts , 1975. 
[19] M. Cubrinovski and K. Ishihara, "Maximum and minimum void ratio characteristics of sands," Soils and Foundations, vol. 42, no. 6, pp. 65-78, 2002.

[20] “COMSOL," https://www.comsol.com/documentation, 2014.

[21] J. F. Labuz and A. Zang, "Mohr-Coulomb Failure Criterion,” Rock Mechanics and Rock Engineering, vol. 45, pp. 975-979, July 2012.

[22] American Concrete Institute, Building code requirements for structural concrete (ACI 318-95) and commentary (ACI 318R-95), The Institute, 1995.

Copyright $(\mathrm{C}$ by the authors. Licensee TAETI, Taiwan. This article is an open access article distributed under the terms and conditions of the Creative Commons Attribution (CC BY-NC) license (https://creativecommons.org/licenses/by-nc/4.0/). 